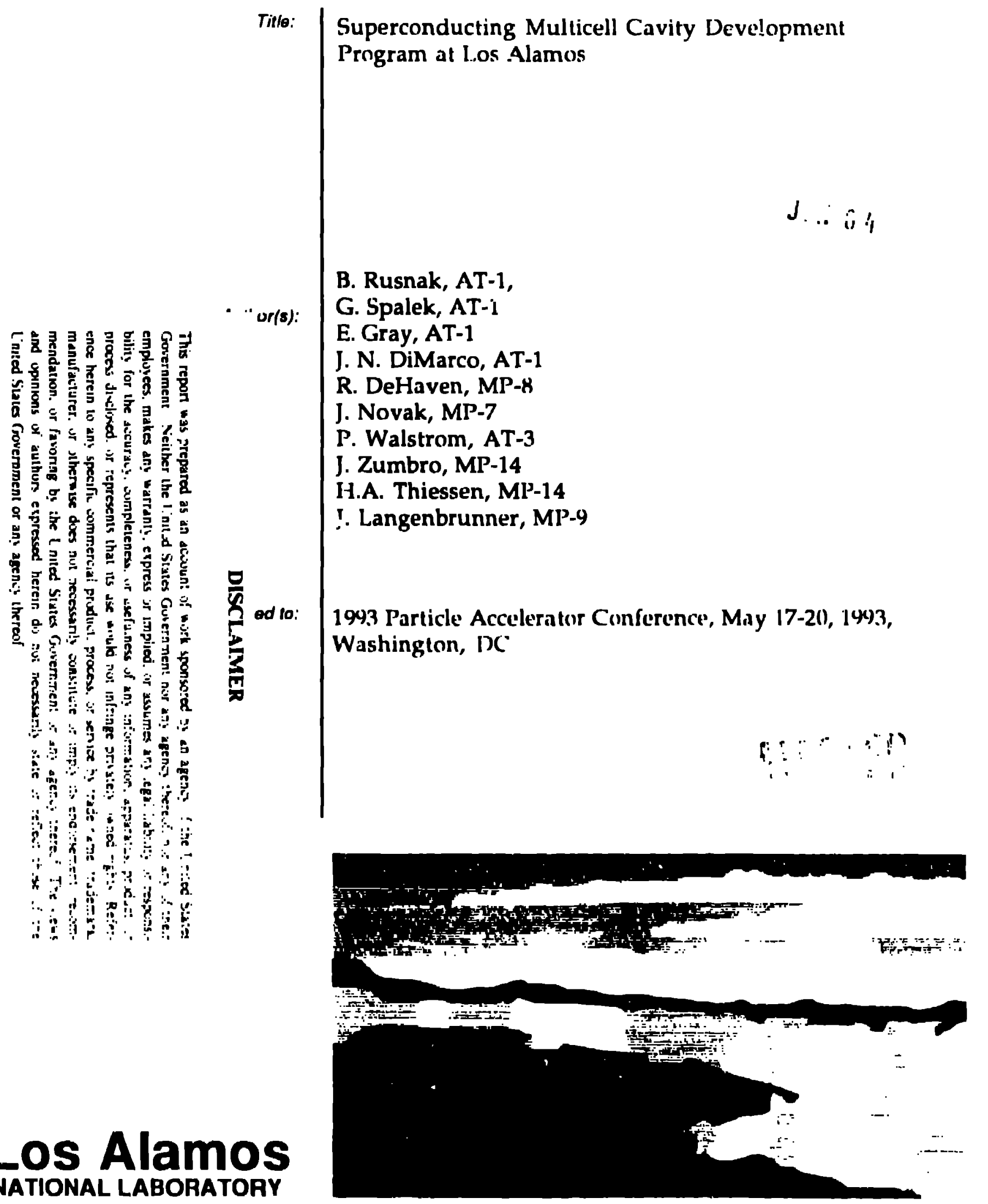

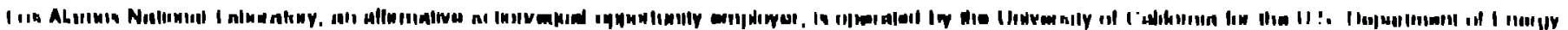

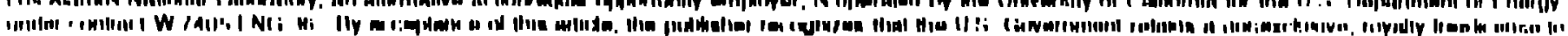

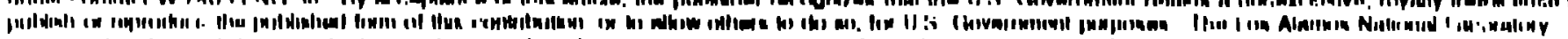

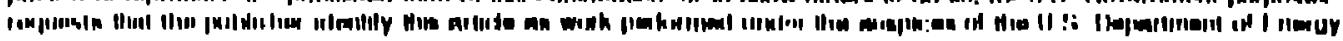




\title{
Superconducting Multicell Cavity Development Program at Los Alamos*
}

\author{
B. Runak, (i. Spalek. E. Giay, J. N. LiMaroo, R. I) Haven. J. Newath. \\ P. Walstrom, J. Zumbro, H. A. Thessen, and J.Langenbrunner** \\ I os Alaunos Natumal Laboratory \\ Les Alimos, NM 87544 USA
}

\begin{abstract}
Abstreste
The Superconducting of (SCRF) Cavily Develupment Program at Los Alamos has designed, fabricated, and tested single-cell niohium cavities at T-GHz and k05-MHz. This work is being done in preparation for procuring and testing a multicell nothium cavity. The multicell cavity is designed to accelerate protons at $\beta=0.9$; intial tests will be without beam. Programmatlic changes have reyured us to modify our plans 10 install a $68(k)$-liter helium cryostat and a $12.8-\mathrm{g} / \mathrm{s}$ helium pump. We will lise an installed cryostat to kest the multicll cavity. Also. the cavity will be modified from a seven-cell to a t(wij-cell structure to match the dimensions of the installed, yostat. Previous reports concentraled on 3 (ille results. In thes paper, some of the latest results of the 8015-M!le bavity tests are presented. Modifications 10 allow high pulsed fower (HPP) testing on $80.5 \mathrm{M} / \mathrm{H}$ single- and tour-cell cavities are proceeding. (ilow discharge cleaning of ath 805 . MHz mohium cavity resulted in a decrease in cavity peiformatuce, The cavily was restored (1) previous performance levels with buffered chemical pofishong (txpl). Initial results with high-pressure water cleanil show the process is usedul in restoning cavily performance.
\end{abstract}

\section{INITROI)(IC IIION}

The primary poial of our SC RF propram is develupment

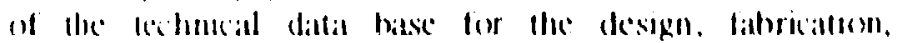
hamdlang. and testing of supereonducting (SC) cavitus that

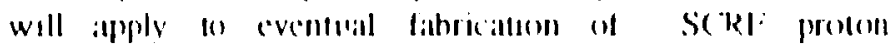
ancelenattus.

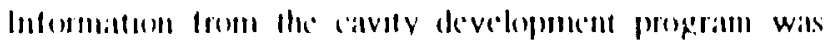

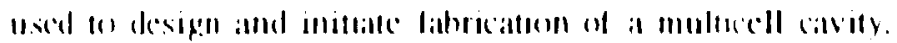

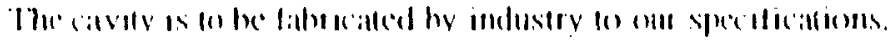

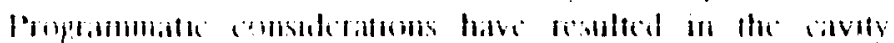

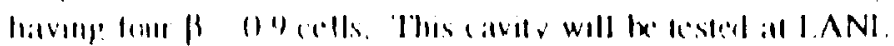

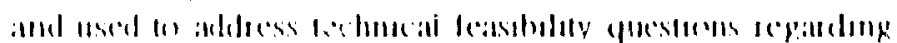

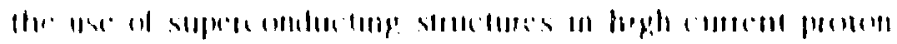
an relctialus

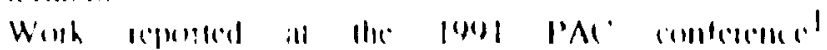

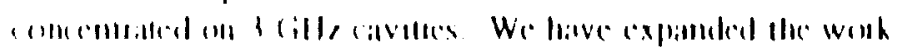

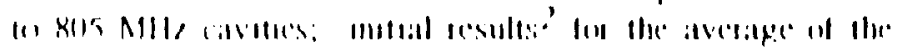

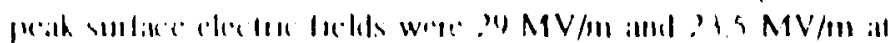

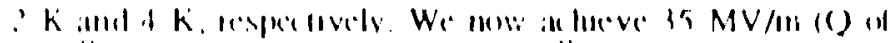

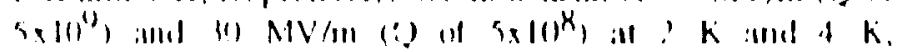
mereacely

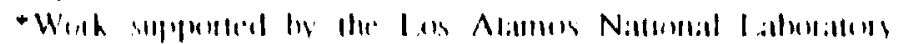

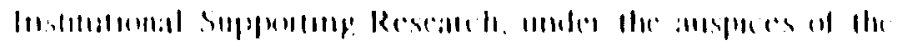

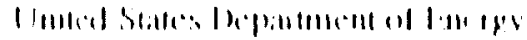

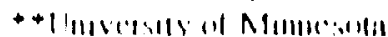

Our investigation of deaning technichues has concentrated on systems that could adso be used on the fourcell cavily. High-pressure pure-water splaty is a viaht: technique for removing particulates from the surface of the niobium. We have tested an $805 \mathrm{M} / \mathrm{M}$ single-cell cavily dhat was initially cleaned in the standard way by a bep. The cavity

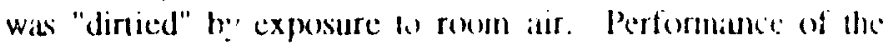
avily was restored after high-pressure deaning. This equipment is being modified oc clean the four-cell cavity.

\section{MUL,TICELL C AVITY}

A cavity structure consisting of seven mishoum savities, supporting structure, and tuning svistem has heen destribed in a previous pubicication? "This structure consisted of seven $\beta=$ 0.9754 cells. For prongrammatic reasems. the cell shape " w changed to $\beta=0,4$ to match $12(x)-M e V$ promons. Also, 1 . mumber of cells in the cavity was reduced from seven 16 , foun. A four-cell cavity comforms lo defencel power hamdling comstrants of windowsicouplers in conceptual designes of some high power proton accelenaters. The smallet strueture also áts inte a cryostat that ss presently instadled on the sc latheratury. The new eavily also includes hiph osder mode

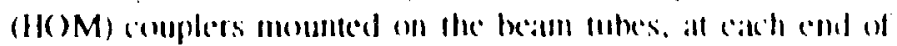
the cavily. Windew and variable couples kests have started in preparation for l(K) kW pulsed a power comditionimg: lests. init.illy with single K(19-MHle cells.

\section{SINGIIT-GIII, RISSIIITS}

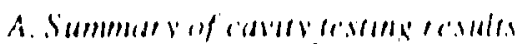

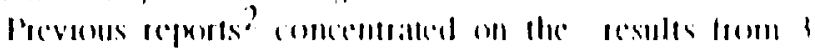

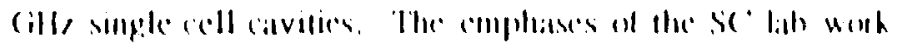

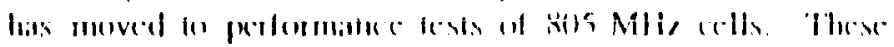

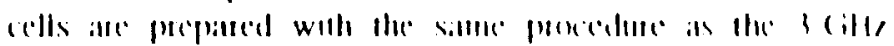

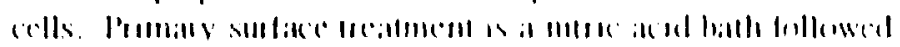

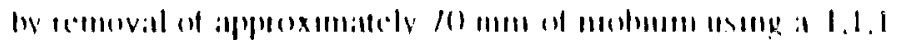

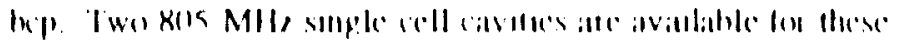

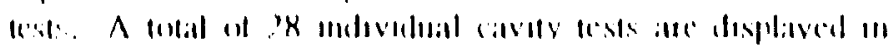

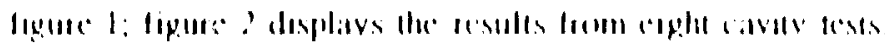

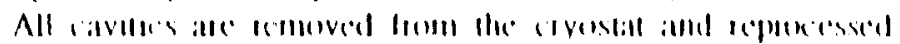

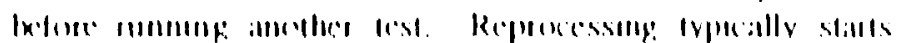

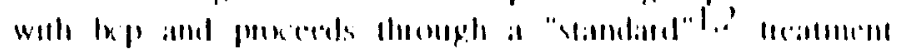

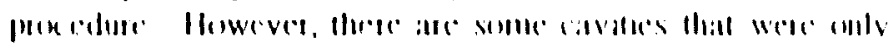

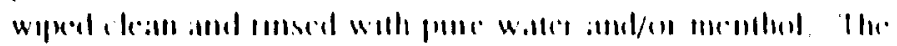

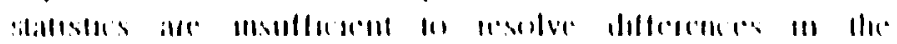

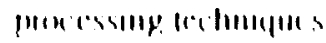

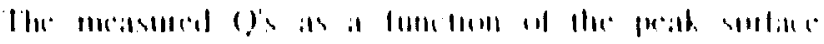

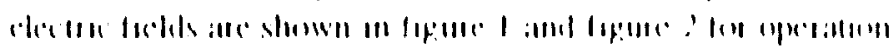


at ? $\mathrm{K}$ and $4.2 \mathrm{~K}$, respectivele. Some of the lests reyutre an mitial conditumer of the cell by gradually increasing $r$ (n)we:

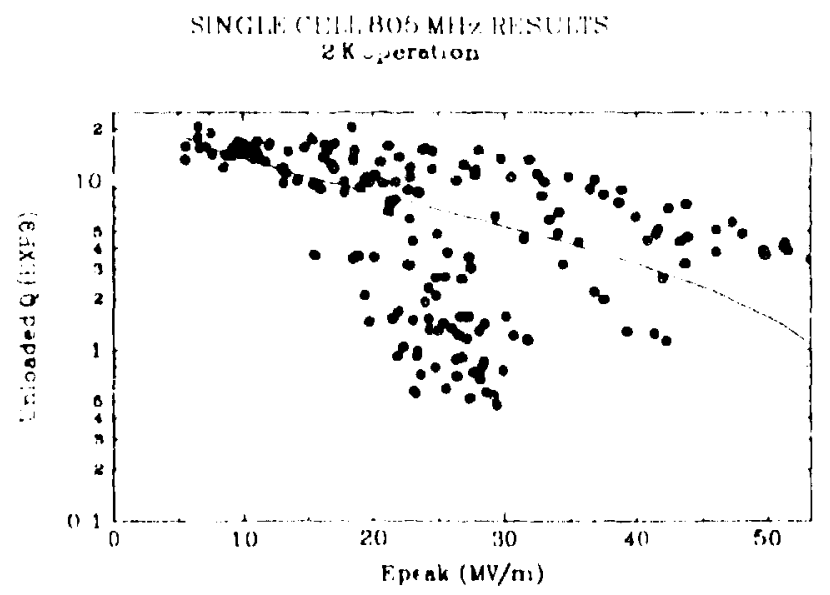

Pigure. 1. Q vs. Peak surtiace olectric field at $2 \mathrm{k}$. Dotted lines indicalte $95 \%$ conlidence level.

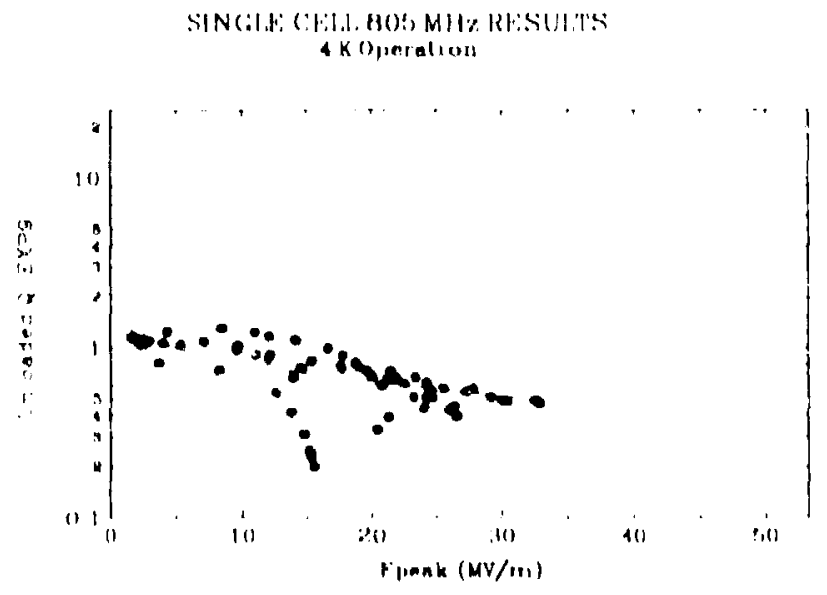

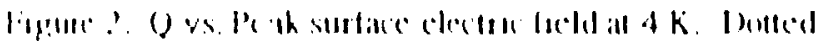

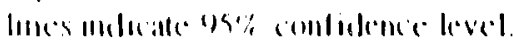

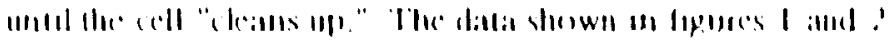

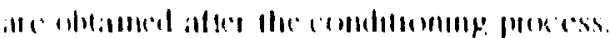

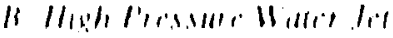

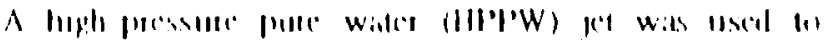

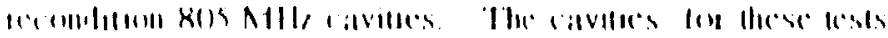

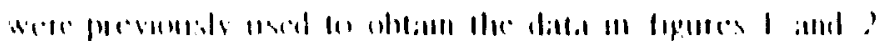

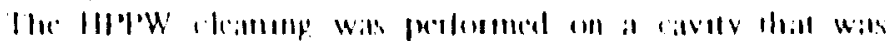

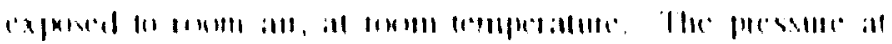

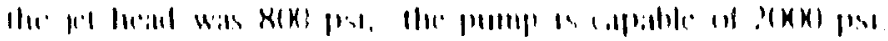

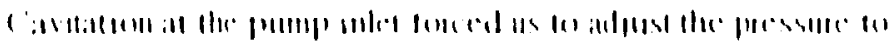

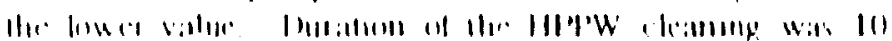

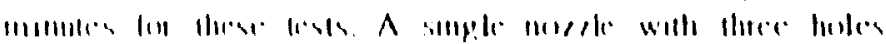

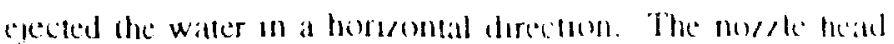

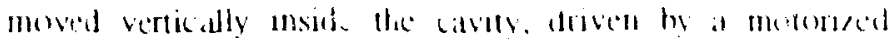
drive sorew at the rate of 5 om/minutc

At this teme, three bavity lests have be:all dome. The

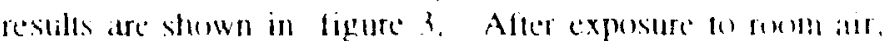
the

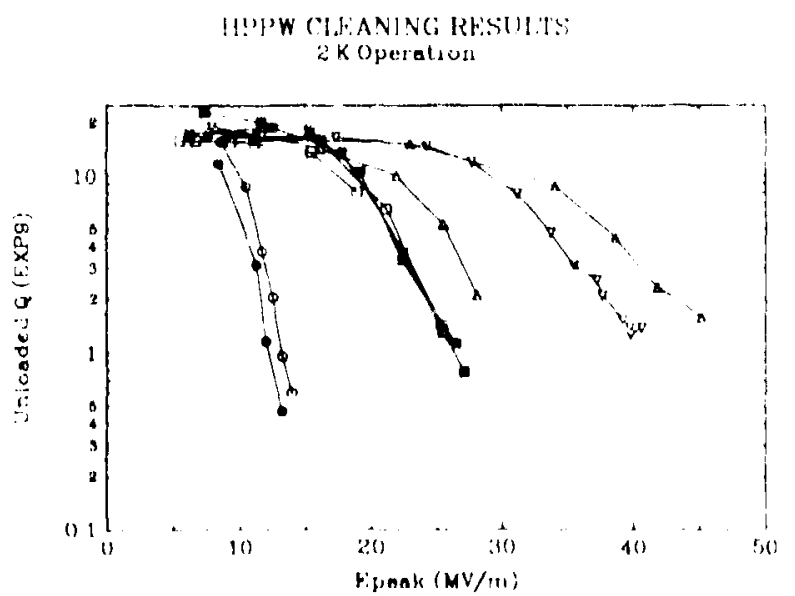

Figure? $Q$ vis peith surtiace fichl all $2 \mathrm{~K}$. i) (avils pertormatice aller exposure (1) romill atir (cirche), b) Cavily periormance alter !irst HIPPW cleaning (lxix), () (atvity pertormatice after second HIPPW cleaning (triangle).

cavity performathe was degrated due wh havy chectron lobdeng. Aller sleaning with HIP'W, the prerlomiance impreved, allamimg some of the highest values for all bavily tests.

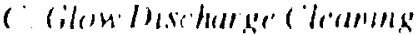

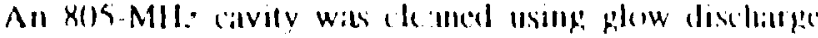

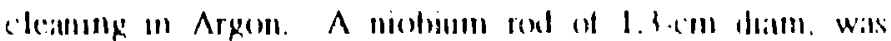

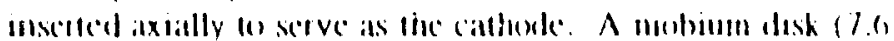
(m) diat. (1)." ('m thick) wis mounted at the cond of the rod and

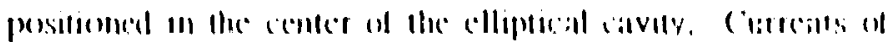
alperosumately $3(k)$ mat at voltages of $f(x)$ volls were

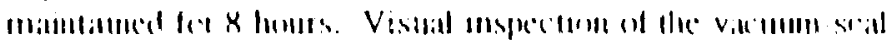

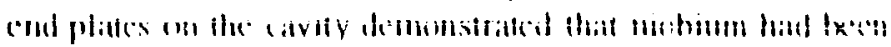

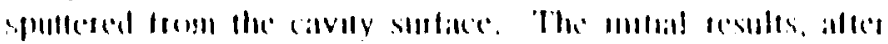

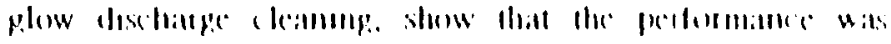

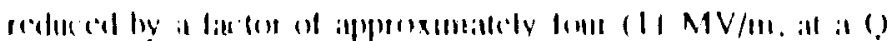

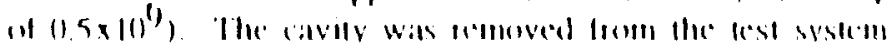

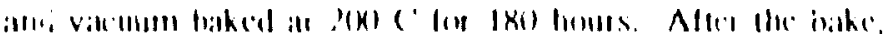

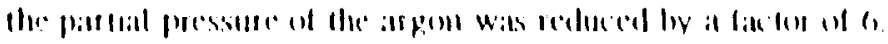

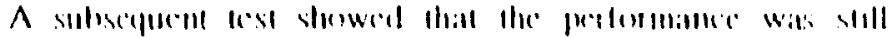

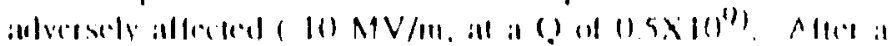

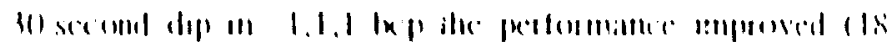

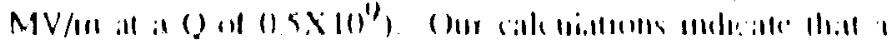

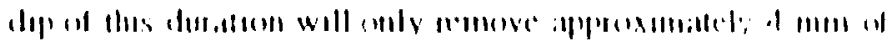

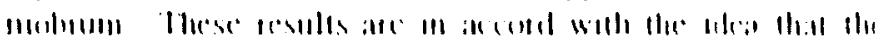

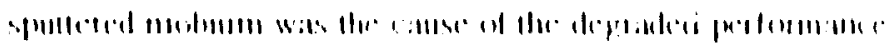
il thes candly 


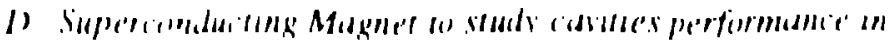
al) mill

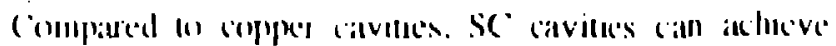
substantailly greater accolerattung pradents with meglighble dhermal loss in the cisities. A pariumeter relatted lo the

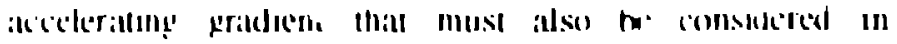

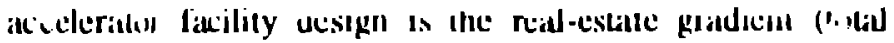
pintential chamge/fotad length of acceleraltor). Dependeng on the ficility pariuneters maximizing the real-estalle gradient (atl be of mator injporiunce. (ne possible waty of doing this will $S C^{\prime}$ structures is through the use of fixusing elezilents thall operille all cryogemic lemperatures. Such lixusing rlements can climinille transitun to romen temperallure, and

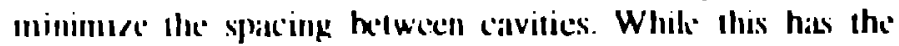
idvalntage of an mereasiol real extalle gradient, there art siveral polential problems:

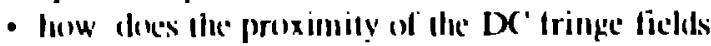

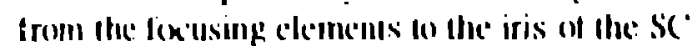
cavities aflect dice perfonmante of the cavity?

- hou difficoli is il lo recover trom a cilvity yutenchi!

The study' thesce problems. we have consinucled a smatl $15.7 \mathrm{~cm}$ long hy $4.4 \mathrm{~cm}$ inside diamelers) solemoid with

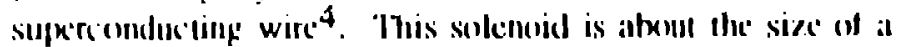

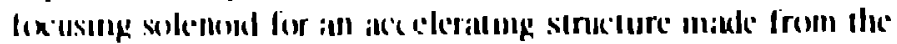

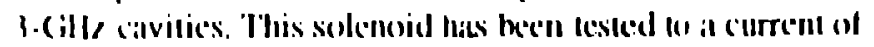
l(x) Amperes where the (entral. oll-axis, fuell was measured

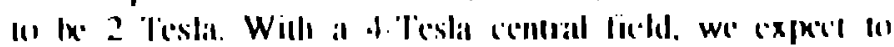

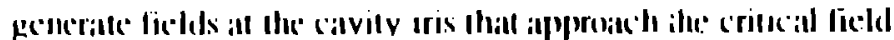

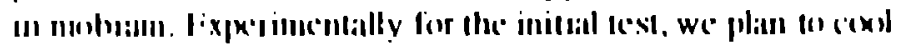

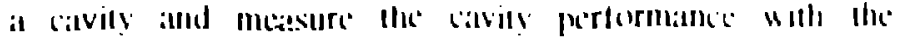

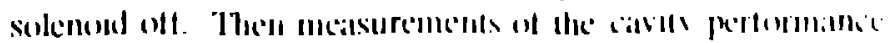

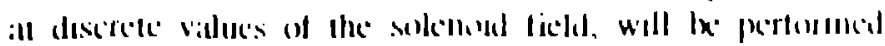

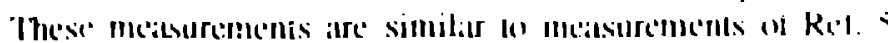

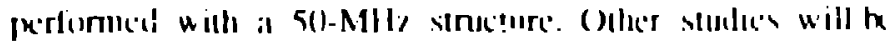

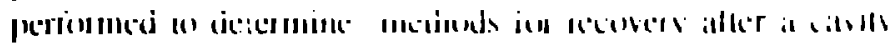
ydent h in th. presence ol the L, magnelic teld.

\section{REFFRI:NCLS}

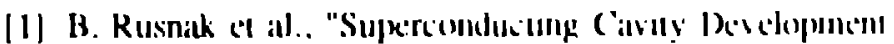
al IAs Alaunos National baburatory." contereme Recoral

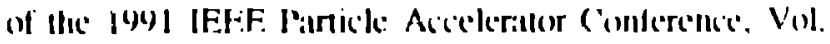
2. 1). I1146-1(147.

[2] 13. Kusnak. a al.. "Evaluallon of Surlate Comtaninatun

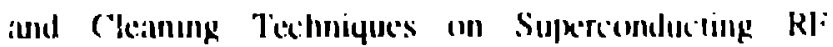

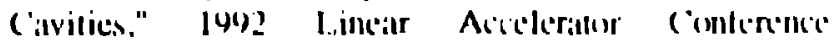
I'rocecodings, Vol. 2. pl). $728-7311$.

|1 D. J. Liskal el al., "l Design Features of a Sevin (e:ll

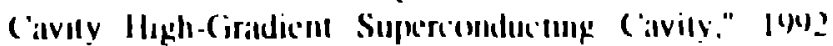

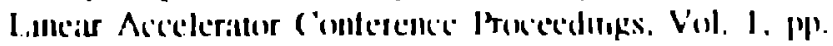
163.165.

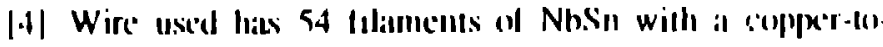

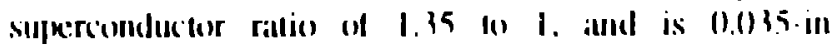
diameter (without insulation). Instalituon of tormvar wass atded lo bring the wire diame'ter $10(1.0177$ inches.

$|5|$ R. Benarova and K. W' Shepitrd, Kev. Si'i. Lusinuments 54. 2I (1) (I0)X). 